\title{
Hedge Accounting Determinants and Consequences: New Evidence from Brazilian Companies
}

\begin{abstract}
We investigated the determinants and the consequences of hedge accounting as an accounting choice in the Brazilian capital market. We analyzed a sample of 187 nonfinancial firms which used derivatives or non-derivatives to risk management from 2010 to 2017. We contributed with two new proxies for the assessment of hedge accounting practice. The first hypothesis is to analyze whether companies that use hedge accounting have a higher maximization of firm value. The second hypothesis is whether companies' earnings were smoothing less than practices this policy and the last one is if hedge accounting is being used to avoid violated debt covenants. These findings suggest that companies in the cluster with the highest level of hedge accounting designation in the periods had a positive and significant relationship with the higher firm value, corroborating the prior literature. We can identify that companies that designated a lower amount of derivatives to hedge accounting indicated a higher trend of income smoothing. These findings corroborate the main purpose of hedge accounting that is a reliable representation of risk management in the financial statements. We did not find evidence that proximity to violate covenants as a determinant for adoption or the higher level of adoption derivatives for hedge accounting.
\end{abstract}

Keywords: Hedge Accounting; firm value; earnings smoothing; debt covenants

\section{Introduction}

This study aims to analyze the determinants and consequences of the accounting choice of hedge accounting in the Brazilian market. Thus, we seek to contribute with 
empirical evidence of hedge accounting, highlighting its relationship with the maximization of the firm's value, its impact on the earnings smoothing, and analyze whether the choice of hedge accounting is being used for non-violation of covenants.

Until the early 1990s, much of the information on derivative instruments was off-balance sheet, unrecognized, or recorded at historical cost only. Derivative registration was strongly opposed by companies, arguing that the implementation rules were excessively complex and would increase the volatility of results (Lins, Servaes, \& Tamayo, 2011)

With the change in accounting standards, which now provide for the recognition of these instruments, this information is now measured in the financial statements and evidenced by footnotes (Allayannis \& Ofek, 2001; Judge, 2007). At the same time, the academic area has evolved in risk management research, primarily due to the development of the theoretical framework of corporate hedge determinants and the availability of data caused by changes in accounting standards (Judge, 2006).

The Brazilian Securities and Exchange Commission (CVM) presents a growing importance of the derivatives market, in line with the growth of such market in the global economy (dos Santos, Lima, Gatsios, \& de Almeida (2017)). Besides, the Brazilian economy is one of the ten biggest economies in the world and very exposed by interest and exchange variations, meanly by dollar and euro. Moreover it presents one of the most commodities volumes products. For this reasons, study hedging in Brazilian context can contributed to investment analyses and standard setters understand how the companies will be impact and determinants of accounting choice in financial statements.

In Brazil, this theme gained momentum with the harmonization with international financial reporting standards. Initially, in 2008, with the standard of 
Financial Instruments: Recognition, Measurement, and Disclosure, it established the main concepts related to the recognition and measurement of financial assets and liabilities. And in the second stage, in 2010, with the complete adoption of international accounting standards, which are based on IAS 39, 32 and IFRS 7. These standards deal with financial instruments, forms recognition, measurement, presentation, and disclosure.

This standard filled a gap in the Brazilian standardization of non-financial corporations regarding disclosure of these operations. According to Capelletto, de Oliveira, and Carvalho (2007), "(...) knowledge of the economic and financial situation of the company depends on the disclosure of information that adequately reflects the effects of hedge operations on protected positions."

Due to the increase in risk management practices by companies, it is important to identify the determinants and consequences of hedge accounting. There is still little empirical evidence on how hedge accounting standards, such as IAS 39, SFAS 133, or IFRS 9, influence the risk management of non-financial corporations (Glaum \& Klöcker, 2011).

To address this question, we composed a sample from 2010 to 2017 with companies that used derivatives or natural hedge in at least one of these years. And we analyzed three hypotheses related to this theme. The first one is if companies that use hedge accounting have higher maximization of firm value. The second one is if companies' earnings are smoothing less than practices this policy and the last hypothesis is if hedge accounting is being used to avoid violated debt covenants.

This paper contributes with two new proxies for the assessment of hedge accounting practice. The first one is obtained by the notional ratio of hedge accounting and derivatives and non-derivatives and the second one by the clustering of this 
historical hedge accounting ratio about the total volume of derivatives and nonderivatives.

The main results obtained in hypothesis one were that companies in the cluster with the highest level of hedge accounting designation in the periods have a positive and significant relationship with the higher value of the firm. This same relationship was not found in the hedge accounting ratio or dummy to hedge accounting practices.

In hypothesis 2, the relationship between earnings smoothing and hedge accounting was analyzed. Hedge accounting allows the volatility of derivative financial instruments to be reduced by matching the hedged item and the hedging instrument so that the change in fair value does not impact the period result and, therefore, accounting represents the effect of the hedging activities risk management of companies using financial instruments.

The literature presents earnings smoothing that has numerous benefits, including more informative stock prices (Tucker \& Zarowin, 2006), improved earnings persistence and predictability (Subramanyam, 1996), reduced cost of bankruptcy (Trueman \& Titman, 1988).

Based on the results presented, we can identify that companies that adopt a lower volume or hedge accounting practice have higher practice of income smoothing. These findings corroborate the literature that the practice of hedge accounting presents an earnings smoothing. Due to the matching of derivatives and hedged items, companies would be less likely to practice earnings smoothing. These results corroborate the view of hedge accounting as the main purpose of a reliable representation of accounting operations and not as a practice of earnings management to intentionally reduce results for the period. 
In hypothesis 3, as far as we know, no other papers have performed this analysis of the accounting choice to adopt hedge accounting due to the violation of covenants. As widely studied in the accounting choice literature, managers make accounting choices to increase their results due to the proximity of accounting clause violation (Holthausen \& Leftwich, 1983; Smith \& Warner, 1979; Watts \& Zimmerman, 1986).

In this hypothesis, based on these results, the only model in which the covenant slack was significant was by hedge accounting level and with the non-lagged variable, but with a negative relationship, so it can be inferred, that even in case of a relationship between these variables hedge accounting would have an opposite relationship with proximity to covenants. Therefore, hypothesis 3 of covenant slack cannot be accepted as a determinant for adoption or the higher level of adoption derivatives for hedge accounting.

As an additional analysis, 66 companies which used cash flow hedge accounting and had covenant clauses that allowed recalculation to identify whether some of them failed to breach the clause as a result of hedge accounting were found. Only two companies were found to be able to comply with the covenant clause by adopting hedge accounting.

The results obtained can be regarded as a contribution to market agents, investors, creditors, preparers of financial statements since they indicate a close association between greater adoption of hedge accounting practices to reflect in corporate reports, companies' efforts to mitigate exposure to variable factors, such as exchange rate disparity and interest rates. Moreover, such results can considered of interest to regulatory agents since these findings may encourage the broadening of the adoption of hedge accounting, which lies within the scope of accounting choices. 
The remainder of this paper is organized as follows: section 2 - presentation of related literature and its implications for the development of formulated hypotheses; section 3 - indication of the methodological procedures adopted; section 4 - presentation of the results found, as well as their analyses; and section 5 - final considerations and indications of opportunities for future research in the announced context.

\section{Literature Review and Hypotheses}

\subsection{Hedge Accounting and Maximization of Firm Value}

The purpose of hedging is to use the market to reduce certain risk exposure (Hull, 2005). The theoretical framework related to the determinants of hedge developed from the relaxation of the friction of the seminal paper of Modigliani and Miller (1958). Based on the assumptions of the perfect and frictionless market, risk management strategies would be irrelevant to maximizing firm value, due to the possibility of portfolio diversification by shareholders.

Hedge determinants are generally studied through market imperfections that would increase firm value, including managerial risk aversion costs (Smith \& Stulz, 1985; Stulz, 1984), bankruptcy costs (Mayers \& Smith, 1982; Smith \& Stulz, 1985), progressive tax burden (Smith \& Stulz, 1985) external financing cost (Froot, Scharfstein, \& Stein, 1993), and informative degree of results and managerial reputation. (Breeden \& Viswanathan, 1998; DeMarzo \& Duffie, 1995).

Hedge accounting aims to reflect the operation within its economic essence, to solve the problem of confronting income/gain and expense/loss (Lopes, Galdi, \& Lima, 2011). The application of this form of accounting changes the measurement basis of hedged items or hedging instruments. It is an optional methodology. Nevertheless, the 
company must comply with the requirements presented in the standards, such as effectiveness tests, documentation for designation, among others.

These requirements result in additional protection costs. As a result, some companies decide not to apply hedge accounting and accept greater volatility of results (Glaum \& Klöcker, 2011). Theoretical papers show that hedge accounting has the power to influence companies' hedge strategies (e.g. (DeMarzo \& Duffie, 1995)).

In this context, some studies have found evidence of applying hedge accounting and reducing the volatility of results (Pierce, 2015; Silva, 2014; Zhang, 2009). Panaretou, Shackleton, and Taylor (2013) found that IFRS hedge accounting reduces analyst forecasting errors and dispersion so that results become more predictable.

Pierce (2015) presents the impact of hedge accounting on two-channel marketbased risk. The first one refers to the volatility of the result as a risk measure, and the second channel, due to the "certifying" hedge accounting effect which investors consider to be more effective for risk management.

In Brazilian context, dos Santos, Lima, Gatsios, and de Almeida (2017) investigated the relationship between financial risk management and shareholder value creation for non-financial companies. The authors found that most companies use derivatives to manage cash flow but do not add value to the company. They also analyzed the effect of hedge accounting on the value of the company. However, no evidence was found. The justification for these results is that the number of companies that perform hedge accounting is scarce due to the complex documentation required.

Based on the literature of hedge determinants, companies seek to conduct hedge strategies to maximize corporate value and hedge accounting, which, besides not impacting corporate results with the volatility of financial instruments, still have rules 
that determine the percentages that must be met to be considered protection. This research presents the following hypothesis:

Hypothesis 1: Companies that designate a higher volume of hedge accounting instruments have a higher firm value.

\subsection{Earnings Smoothing and Hedge Accounting}

The practice of hedge accounting allows the matching between the hedged object and the hedging instrument, which represents the economic essence of the operation by its risk management. This process also promotes reduction in the volatility caused by these instruments and, as a consequence, allows greater earnings smoothing.

Earnings smoothing can be defined as the intentional reduction of fluctuations to a level of earnings that is currently considered normal for the company (Beidleman, 1973). Smoothing practice provides evidence of numerous benefits, such as more informative stock prices (Tucker \& Zarowin, 2006), improved earnings persistence and predictability (Subramanyam, 1996), reduced cost of bankruptcy (Trueman \& Titman, 1988). ), lower returns and risks (Michelson, Jordan-Wagner, \& Wootton, 1995).

Graham, Harvey, and Rajgopal (2005) report that executives believe that smoothing results improve predictability, and more than $75 \%$ of the respondents would be willing to sacrifice economic results to achieve smoothing. They would be much less likely to perform some kind of earnings management discretion under accounting standards, though.

Barton (2001) presents that companies use derivatives as partial substitutes in earnings management strategies to smooth results. The author states that derivatives not only reduce cash flow volatility, but also have an indirect effect on accruals. Pincus and Rajgopal (2002) analyzed the oil and gas sector to check whether companies use hedge and abnormal accruals as substitutes to smooth earnings volatility. The authors found evidence that managers take hedge positions regardless of abnormal accrual decisions, 
but in the fourth quarter, mainly, they replace them for abnormal accruals and derivative hedge to control period volatility.

Tessema and Deumes (2018) analyzed the impact of SFAS 133 on earnings smoothing through discretionary accruals and the ineffectiveness of hedge accounting. The authors found that companies that have full hedge effectiveness use fewer earnings smoothing practices and are less affected by market volatility, while companies that have total hedge accounting ineffectiveness have the opposite situation. This paper aims to identify whether companies whose earnings smoothing through discretionary accruals have a lower volume of instruments for hedge accounting.

Hypothesis 2: The earnings smoothing through discretionary accruals is higher for companies that designate a lower volume of hedge accounting instruments.

\subsection{Debt Covenants and Hedge Accounting}

Hedge accounting is an optional accounting practice under the rules of IAS 39, SFAS 133 and IFRS 9. Research that analyzes the determining factors and motivations for choosing different accounting practices by the company is in accordance with accounting choice studies. This line of research seeks to explain the choice of companies by a particular accounting method (Fields, Lys, \& Vincent, 2001;

Holthausen \& Leftwich, 1983; Watts \& Zimmerman, 1986).

Corporate debt has much of its development based on agency theory (Jensen \& Meckling, 1976). In the case of covenants, they are treated as external monitoring costs by bondholders, owner-administrator, so that they ensure monitoring in the least costly way.

There are no reports of studies that have tested whether restrictive clauses impact the choice of hedge accounting practice. We seek to identify whether the proximity of covenant breach would be one of the determinants that drive the choice of hedge accounting. 
In Brazil, the discussion of the impact of debt on companies is very relevant, according to data from CEMEC (Center for Studies of IBMEC), the volume of debt of non-financial companies in the $2013-2017$ period is approximately $50 \%$ of GDP.

The debt hypothesis states that managers make accounting choices to increase their results due to the proximity of breach of accounting clauses (Holthausen \& Leftwich, 1983; Smith \& Warner, 1979; Watts \& Zimmerman, 1986).

Hedge accounting is analyzed in this paper because it allows the volatility of financial instruments to have no impact on net income for the period. In this sense, the company, due to the proximity of covenant violation, could have the incentive to apply this accounting methodology on its operations.

Hypothesis 3: Companies that designate a higher volume of hedge accounting instruments are closer to violate covenants.

\section{Sample Selection and Method}

\subsection{Sample}

The first companies which adopted hedge accounting were from 2008. We selected an initial sample that included all non-financial companies open from 2008 to 2017 listed in CVM . Finance companies were excluded from the sample due to specific criteria required by accounting standards.

The year 2008 was chosen because it was the first year in which the use of hedge accounting was approved. Nevertheless, in the first two years (2008 and 2009), it was adopted by a very small number of companies, 13 and 22 respectively. In 2010, the number of companies using it increased to 39 companies. Therefore, these two years were removed from the sample, as adoption was still incipient.

From the total sample of 331 companies, only the companies which had the use of derivatives or non-derivatives informed in the footnotes, at least, in one of the years 
from 2010 to 2017 , were selected. It is important to mention that the non-derivative instruments considered in the calculations were taken exclusively from the information presented by the company of use as hedge instruments, predominantly the nonderivative instruments were used as cash flow hedge accounting. These criteria were used to reach a sample in which the company would have the possibility to choose the hedge accounting practice. Finally, the sample analyzed comprised 187 companies from 2010 to 2017

It is noteworthy that the use of derivatives and non-derivatives was considered a hedging strategy. Primarily, companies report that they use derivative instruments for the sole purpose of hedging. It was not the object of the study to identify whether companies effectively use these instruments for protection.

\subsection{Hedge Accounting proxies}

In this paper, we use 3 proxies for hedge accounting:

1) HA_RATIO (hedge accounting ratio)- is calculated by dividing the total notional of derivative and non-derivative financial instruments designated for hedge accounting divided by the total of notional derivative and non-derivative instruments used by the company at the balance sheet date generating a hedge accounting ratio ranging from 0 to 1.

2) CLUSTER_HA - It is built by clustering companies by the HA_Ratio level from 2010 to 2017 . The clustering was performed based on distance measurements since the variable selected for the formation of groups is metric. HA_Ratio, which ranges from 0 to 1 , is a variable formed by the notional division designated as hedge accounting. For cluster formation, the following steps were performed. The HA_Ratio column was divided by the years in which the company performed hedge accounting, resulting in an average of designated hedge accounting percentage. With this 
information by the company, a cluster analysis was performed to obtain homogeneous groups in hedge accounting designation characteristics and, thus, provide a closer view of the companies' hedge accounting practice.

3) DUMMY_HA - with a value of 1 for companies which had adopted hedge accounting and 0 for companies which had not adopted it. (dos Santos, Lima, Gatsios, \& de Almeida, 2017; Hughen, 2010; Panaretou, Shackleton, \& Taylor, 2013; Potin, Bortolon, \& Neto, 2016)

The first two metrics (HA_RATIO and CLUSTER_HA) are not known to have been used in the literature before and, thus, present a differential to the use of a dummy because there is a variation among companies that adopt hedge accounting. Therefore, the dummy only evaluates whether the company uses hedge accounting practices, and, thus, it equals companies that use hedge accounting for all their financial instruments to companies that do so only for a low volume of operations. De Matos, de Rezende, Paulo, de Marques, and Ferreira (2013) report that, although most companies use hedge accounting, none of them designated all existing hedges. The use of a proxy that divides the notional amount of hedge accounting designated by the notional value of total derivatives and non-derivatives and as well as by the preparation of clusters may have greater adherence to the essence of the company accounting policy choice.

\subsection{Proposed Models}

\section{Model 1: Hedge accounting and firm value maximization}

Model 1 seeks to verify whether hedge accounting is significant for the increase in firm value, as proposed by the hedge determinants (Smith \& Stulz, 1985).

$$
Q T_{i j}=\beta_{0}+\beta_{1} \text { Metric_H } A_{i j}+\sum_{k=1}^{w} \text { Controls }_{k i j}+e_{i j}
$$


The impact of the firm's hedging strategy on the company value is assessed in this paper by the Tobin Q (QT) metric. The choice of this proxy is justified by its wide use in empirical works that evaluate this relationship. (Allayannis \& Ofek, 2001; Allayannis \& Weston, 2001; Aretz \& Bartram, 2010; Bartram, Brown, \& Conrad, 2011; dos Santos, Lima, Gatsios, \& de Almeida, 2017). The hedge accounting proxies used are CLUSTER_HA, HA_RATIO, and DUMMY_HA, as defined in item 3.2 Hedge Accounting proxies.

The control terms are the log of total assets $(L A T)$, which reflects firm sizes (Allayannis \& Weston, 2001; Allayannis \& Ofek, 2001; Aretz \& Bartram, 2010; Bartram et al; 2011; dos Santos, Lima, Gatsios, \& de Almeida, 2017; Galdi \& Guerra, 2009; Silva, 2014,); the Q Tobin Lagged (QT $\left.\mathrm{t}_{\mathrm{t}-1}\right)$, which reflects market expectations (Allayannis \& Ofek, 2001; Allayannis \& Weston, 2001; Aretz \& Bartram, 2010; dos Santos, Lima, Gatsios, \& de Almeida 2017.; Bartram, Brown, \& Conrad, 2011), the return on assets $(R O A)$, which reflects profitability (Allayannis \& Ofek, 2001; Bartram et al; 2011; dos Santos, Lima, Gatsios, \& de Almeida, 2017); derivatives proportion (DER_ASSET), which reflects the risk exposure which companies try to protect themselves (dos Santos, Lima, Gatsios, \& de Almeida, 2017); Leverage (LEV) - debt of long term scaled by total assets (Allayannis \& Ofek, 2001; Bartram et al; 2011; dos Santos, Lima, Gatsios, \& de Almeida, 2017), Liquidity (LIQ), which reflects financial restriction (Allayannis \& Ofek, 2001; Bartram et al; 2011; dos Santos, Lima, Gatsios, \& de Almeida, 2017), Beta (BETA), which reflects volatility of companies (Silva, 2014); Investment Opportunity (INV_OPOR), which reflects company expectation (dos Santos, Lima, Gatsios, \& de Almeida, 2017); Fixed industry (IND), which controls industry specificity; and timeliness (TIM), which reflects potential yearly effects, such as business cycles. 


\section{Model 2: Hedge Accounting and Earnings Smoothing}

Model 2 seeks to verify whether companies which smooth earnings through discretionary accruals have lower volume of instruments for hedge accounting. Thus, the equation of model 2 is proposed below:

$$
\text { SMOOTH }_{i j}=\beta_{0}+\beta_{1} \text { Metric_HA }_{i j}+\sum_{k=1}^{w} \text { Controls }_{k i j}+e_{i j}
$$

This Smoothness variable (SMOOTH) represents that managers exercise accounting discretion to earnings smoothing which is in accordance with previous studies (Tessema \& Deumes, 2018; Tucker \& Zarowin, 2006). The smoothing measure used is the correlation between changes in managed results and changes in unmanaged results. This measure is based on the Modified Jones Model (MJM) by Kothari, Leone, and Wasley (2005) in which discretionary accruals are calculated based on the residuals of the equation.

The calculation of this equation, as in Tucker and Zarowin (2006) and Tessema and Deumes (2018), is performed for each fiscal year and industry using the ordinary least squares regression. From this value, the smoothing metric is calculated by correlating the change in pre discretionary accrual with the variation in discretionary accrual using three-year or four-year observations. This variable shows that the more negative this correlation is, the greater the earnings smoothing.

$$
\begin{aligned}
& \text { SMOOTH } \\
& \text { it }=\text { Corr } \frac{\triangle P D I}{\triangle D A P}=\frac{\triangle P D I}{\Delta(N I-P D I)}(4) \\
& \text { PDI = Pre discretionary accrual } \\
& \text { DAP = Discretionary Accruals } \\
& \mathrm{NI}=\text { Net Income }
\end{aligned}
$$


The hedge accounting proxies used are CLUSTER_HA, HA_RATIO, and DUMMY_HA, as defined in item 3.2. Hedge Accounting proxies. The control terms are $\log$ of total assets $(L A T)$, the return on assets $(R O A)$, Leverage (LEV); Beta (BETA); Investment Opportunity (INV_OPOR); Fixed industry (IND), which controls industry specificity; and timeliness (TIM), which reflects potential yearly effects, such as business cycles. The control terms are described in the model 1.

\section{Model 3: Hedge Accounting and Debt Covenants Hypothesis}

Accounting choice literature shows that companies choose different accounting practices so that they do not violate covenant clauses (Fields et al., 2001, Watts \& Zimmerman, 1986, 1990). Hedge accounting is an optional adoption that allows unrecognized results of unrealized gains or losses on derivatives, thus allowing the matching between the hedged item and an instrument. In this scenario, the third hypothesis of this study seeks to identify whether companies that are closest to violating covenant clauses are more likely to hedge accounting. No studies were found that sought to identify this relationship. The variables used were selected based on hedge accounting determinant models (Galdi \& Guerra, 2009; Silva, 2014). Thus, the equation of model 3 is proposed below:

$$
\text { Metric_HA } A_{i j}=\beta_{0}+\beta_{1} \text { Slack_Cov }_{i t-n}+\sum_{k=1}^{w} \text { Controls }_{k i j}+e_{i j}
$$

In this model, the Hedge Accounting variable becomes dependent. For this calculation, as the covenants metric is annually linked, only the HA_RATIO and DUMMY_HA metrics were used.

The Variable of interest is Covenant Slack (COV_SLACK). This metric is obtained by dividing the value calculated based on the covenant index and divided by the limit imposed by the clause, thus obtaining a ratio. This variable is widely used in 
the debt covenants literature (Beatty \& Weber, 2003; Dichev \& Skinner, 2002; Kim, Lisic, \& Pevzner, 2010).

For this hypothesis, companies that used derivatives and hedge accounting and which had covenant indices that contained Financial Expense, Financial Revenue or Financial Result in their calculation metric were identified. These items were chosen because they have a direct impact on applying hedge accounting so that the use of this methodology may have a positive impact on the calculation of the index and it allows the company to meet the amount stipulated by the covenant clause. The calculated value was divided by the target value, so that the closer to value 1 , the closer to reaching the covenant target. If the value is less than 1 , the company has already violated the covenants.

To calculate the proximity of covenant violation, the following criteria were performed: 1) If the company informed the number of covenants received, this value was considered; and 2) If the company had not informed the value of covenants, the calculation was based on the values calculated in Economatica.

The control terms are the log of total assets $(L A T)$, the return on assets $(R O A)$, Leverage (LEV); derivatives proportion (DER_ASSET), Liquidity (LIQ), Beta (BETA); fixed industry (IND), which controls specificity of industry. The control terms are described in model 1.

\section{Additional Analysis}

For this analysis, the footnotes of all listed companies that used cash flow hedge accounting were analyzed. This type of hedge accounting was chosen since it is the most used methodology in the market and it is still possible to redo the calculation in the Income Statement for the year. 
Table 1 -Hedge Accounting Models by companies

\begin{tabular}{cccccccccc}
\hline Years & $\mathbf{2 0 1 0}$ & $\mathbf{2 0 1 1}$ & $\mathbf{2 0 1 2}$ & $\mathbf{2 0 1 3}$ & $\mathbf{2 0 1 4}$ & $\mathbf{2 0 1 5}$ & $\mathbf{2 0 1 6}$ & $\mathbf{2 0 1 7}$ & Total \\
& & & & & & & & & \\
\hline Fair Value & 15 & 14 & 14 & 16 & 16 & 26 & 27 & 37 & 165 \\
& & & & & & & & & \\
\hline Cash Flow & 27 & 32 & 33 & 37 & 36 & 41 & 42 & 37 & 285 \\
& & & & & & & & & \\
\hline Net Investment & 5 & 5 & 6 & 5 & 6 & 7 & 7 & 10 & 51
\end{tabular}

Source: Authors

After that, we sought all the footnotes of companies that had restrictive clauses including Financial Expenses, Financial Revenues or Financial Result to recalculate without cash flow hedge accounting.

Three restrictive clauses were identified in this category: EBITDA / Financial Expense, EBITDA / Financial Result, EBIT / Financial Expense. We identified 66 observations in 22 different companies and years.

\section{Results}

\subsection{Descriptive statistics and univariate analysis}

The sample of this study of 187 companies, comprising companies that used derivative instruments in at least one of the years, from 2010 to 2017, is distributed in 10 industries, according to the CVM classification.

Table 2 - Descriptive Statistics

\begin{tabular}{lccccc}
\hline Variable (R\$ million) & Obs & Mean & SD & Min & Max \\
\hline Total Asset & 1,397 & $16,746.15$ & $62,284.75$ & 4.907 & 900,135 \\
Size (Ln) & 1,395 & 12.84624 & 2.56151 & 6.393758 & 16.0675 \\
Notional of Derivatives & 1,323 & $1,687.341$ & $10,292.91$ & 0 & $242,955.4$ \\
Notional of HA & 1,324 & 911.3493 & $9,907.668$ & 0 & $242,065.8$
\end{tabular}




$\begin{array}{lccccc}\text { Q-Tobin } & 1,296 & 1.4182 & 0.8470 & 0.412259 & 6.987566 \\ \text { HA_RATIO } & 1,261 & 0.2010 & 0.3692 & 0 & 1 \\ \text { Leverage } & 1,392 & 0.3360 & 0.1723 & 0 & 0.974279 \\ \text { ROA } & 1,387 & 0.0949 & 0.4682 & -10.262 & 12.87722 \\ \text { Liquidity } & 1,408 & 1.8223 & 2.281888 & 0 & 69.5026\end{array}$

Source: Authors

The use of derivatives and hedge accounting, according to table 2, presents that companies with high variability, with an average of $\mathrm{R} \$ 1,687$ million derivatives and non-derivative hedging instruments used, and with a standard deviation of $\mathrm{R} \$ 10,292$ million. Regarding hedge accounting, which can be observed by the variables Notional of hedge accounting and HA_RATIO, it is seen that companies designate on average $20 \%$ of derivative instruments and with a standard deviation of $36.9 \%$.

Table 3 - Hedge Accounting (HA) and Derivatives (DER) users

\begin{tabular}{ccccccccccc}
\hline Year & 2008 & 2009 & 2010 & 2011 & 2012 & 2013 & 2014 & 2015 & 2016 & 2017 \\
\hline DER Users & 102 & 100 & 118 & 131 & 131 & 130 & 122 & 127 & 128 & 143 \\
HA Users & 13 & 22 & 38 & 41 & 44 & 48 & 47 & 59 & 62 & 68 \\
$\%$ & 12.7 & 22.0 & 32.2 & 31.3 & 33.58 & 36.9 & 38.5 & 46.5 & 48.4 & 47.6
\end{tabular}

Source: Authors

\subsection{Hedge Accounting Cluster}

HA_RATIO data were used to construct the cluster variable, in which the companies were divided by the level of derivative and non-derivative instruments for hedge accounting in relation to the notional of derivatives and non-derivatives used. After the individual calculation per year was carried out, the HA_RATIO averages were calculated, considering only the years in which the company adopted hedge accounting. 
Through the dendrogram analysis and F Test, we could identify two clusters with homogeneous and heterogeneous characteristics among the other groups with the largest distance jump.

Table 6 - Descriptive Statistics of clusters

\begin{tabular}{llllllll}
\hline Cluster & Companies & Obs & Perc.l & Mean & SD & Min & Max \\
& & & & & & & \\
\hline 1 & 112 & 896 & $62.92 \%$ & 0.048 & 0.130 & 0.000 & 0.533 \\
& & & & & & & \\
\hline 2 & 66 & 528 & $37.08 \%$ & 0.878 & 0.149 & 0.562 & 1.000 \\
& & & & & & & \\
\hline Total & 178 & 1,424 & $100.0 \%$ & 0.356 & 0.425 & 0.000 & 1.000
\end{tabular}

Source: Authors

As seen in table 4, cluster 1 presents more than half of the observations. We can see that cluster 1 has the highest number of observations and also the lowest average, while cluster 2 has an average of 0.8784 HA_RATIO and a standard deviation of 0.1485 .

\subsection{Hedge Accounting and Firm Value Results}

Table 5 - Results Panel Data of Hedge Accounting and Firm Value

Panel A - Hedge Accounting and firm value

$$
Q T_{i j}=\beta_{0}+\beta_{1} \text { Metric_H }_{-} A_{i j}+\sum_{k=1}^{w} \text { Controls }_{k i j}+e_{i j}
$$

\begin{tabular}{lccc}
\hline & $(\mathrm{N}=1.056)$ & $(\mathrm{N}=1.056)$ & $(\mathrm{N}=1.111)$ \\
Variables & Cluster_HA & HA_RATIO & DUMMY_HA \\
\hline METRIC_HA & $0.101^{* * *}$ & -0.028 & -0.040 \\
& $(0.034)$ & $(0.045)$ & $(0.038)$
\end{tabular}


Controls

Constant

Adjusted $\mathrm{R}^{2}$

$* * * \mathrm{p}<0.01, * * \mathrm{p}<0.05, * \mathrm{p}<0.1$

Source: Authors

The CLUSTER_HA Random Effects Panel Data Regression Result table shows the results of the Model 1 parameter estimates. This shows:

a) CLUSTER_HA - this variable is positive and significant at the $1 \%$ level with Tobin's Q variable. Thus, a relationship can be identified between the hedge accounting assignment level and the firm value. The companies that are in cluster 2 , whose average designation is higher than the cluster 1 companies would have on average 0.101 higher Q Tobin.

b) HA_RATIO and DUMMY_HA - In both cases, these variables were not statistically significant. It can be inferred from this result that the adoption of hedge accounting which presents relation to the firm value would be related to the adoption of a risk management policy that continuously includes hedge accounting in recent years. For this test, the Hausman test, which showed that the fixed effects model was more consistent, was performed.

\subsection{Hedge accounting and Income Smoothing Results}

To calculate the smoothing of the results, it is necessary to apply the Modified Jones Model (MJM). After applying the MJM, the model residue is obtained, which is the discretionary accumulations (DA).

The smoothing variable is presented by the correlation between the variation of managed results and the variation of unmanaged results using three-year observations (Tessema \& Deumes, 2018; Tucker \& Zarowin, 2006). In literature, this variable can be 
found by the correlation between 3 and 4 years. For the present study, the results were analyzed considering both calculations.

\section{Table 6 - Results Panel Data of Hedge Accounting and Earnings Smoothing}

Panel B - Hedge Accounting and Earnings Smoothing - 4 years Correlation

$$
\text { Smooth }_{i j}=\beta_{0}+\beta_{1} \text { METRIC_HA }_{i j}+\sum_{k=1}^{w} \text { Controls }_{k i j}+e_{i j}
$$

\begin{tabular}{lccc}
\hline & $(\mathrm{N}=1.049)$ & $(\mathrm{N}=1.042)$ & $(\mathrm{N}=1.095)$ \\
Variables & Cluster_HA & HA_RATIO & DUMMY_HA \\
\hline METRIC_HA & 0.019 & $0.084 * * *$ & $0.075^{* * *}$ \\
& $(0.042)$ & $(0.033)$ & $(0.028)$ \\
Controls & Yes & Yes & Yes \\
Dummy Industry & No & No & No \\
Dummy Year & No & No & No \\
Constant & Yes & Yes & Yes \\
Adjusted $\mathrm{R}^{2}$ & 0.018 & 0.006 & 0.006 \\
\hline *** $<<0.01, * * \mathrm{p}<0.05, * \mathrm{p}<0.1$ & & &
\end{tabular}

Source: Authors

\section{Table 7 - Results Panel Data of Hedge Accounting and Earnings Smoothing}

Panel C - Hedge Accounting and Earnings Smoothing - 3 years Correlation

$$
\operatorname{Smooth}_{i j}=\beta_{0}+\beta_{1} \text { METRIC_HA } A_{i j}+\sum_{k=1}^{w} \text { Controls }_{k i j}+e_{i j}
$$

\begin{tabular}{lccc}
\hline & $(\mathrm{N}=1.043)$ & $(\mathrm{N}=1.037)$ & $(\mathrm{N}=1.088)$ \\
Variables & Cluster_HA & HA_RATIO & DUMMY_HA \\
\hline METRIC_HA & 0.014 & $0.143^{* * *}$ & $0.094^{* *}$
\end{tabular}


Controls

Dummy Industry

Dummy Year

Constant

Adjusted R ${ }^{2}$

$* * * \mathrm{p}<0.01, * * \mathrm{p}<0.05, * \mathrm{p}<0.1$

Source: Authors

Yes Yes Yes

No

No

No

No

No

No

Yes

Yes

Yes

0.025

0.0004

1) CLUSTER_HA - The cluster variable was not statistically significant. Thus, it cannot be inferred that the average history of cluster designations impacts the companies' annual smoothing practice.

2) Dummy_HA - hedge accounting dummy variable has a positive and significant relationship with earnings smoothing with a level of $1 \%$ and $5 \%$, with the dependent variable of 4 and 3 years, respectively. The smoothing metric shows that the more negative the value, the higher the practice of earnings smoothing. Therefore, companies that have hedge accounting practices earnings smooth less than companies that do not carry out this practice. For this test, the Hausman test,which showed that the fixed effects model was more consistent, was performed.

3) HA_RATIO - presents a positive and significant relationship at the level of $1 \%$ and $5 \%$, respectively at 4 and 3 years with the smoothing variable. Thus, the lower the designated hedge accounting value is, the higher the earnings smoothing practices. For this test, the Hausman test, which showed that the fixed effects model was more consistent, was performed.

Based on the results presented on this model, we can identify that the companies which adopt higher volume, measured by the HA_Ratio variable, or the hedge 
accounting practice, measured by the HA Dummy variable, have lower practice of earnings smoothing. These findings corroborate the literature (e.g Tessema \& Deumes, 2018) and present that the companies that practice hedge accounting would be less likely to practice earnings smoothing.

\subsection{Hedge Accounting and Covenants Results}

\section{Table 8 - Results of Hedge Accounting and Covenants}

Panel D - Hedge Accounting and Covenants

$$
H A \_R A T I O_{i j}=\varphi+\beta_{1} \text { Cov_Slack }_{i t-n}+\sum_{k=1}^{w} \text { Controls }_{i t-n}+e_{i j}
$$

\begin{tabular}{lcc}
\hline & $(\mathrm{N}=152)$ & $(\mathrm{N}=170)$ \\
Variables & Lagged & Not Lagged \\
\hline Cov_Slack $_{\mathrm{t}-1}$ & 0.004 & $-0.012 * * *$ \\
Cov_Slack $\mathrm{t}$ & $(0.010)$ & $(0.004)$ \\
Controls & Yes & Yes \\
Dummy Industry & No & No \\
DummyYYear & No & No \\
Constant & Yes & Yes \\
Adjusted $\mathrm{R}^{2}$ & 0.344 & 0.270 \\
\hline$* * * \mathrm{p}<0.01, * * \mathrm{p}<0.05, * \mathrm{p}<0.1$ & &
\end{tabular}

Source: Authors

In this model, the COV_SLACK $\mathrm{t}_{\mathrm{t}-1}$, which shows how close the company is to violating covenants, was not statistically significant. The only control variables that were statistically significant in the presence of the others were Beta, Liquidity and Derivative Proportion. 
The COV_SLACK $\mathrm{t}_{\mathrm{t}}$ has a negative and significant relationship at the level of $1 \%$ with the HA_RATIO variable. Thus, the closer the covenant variable, the higher the hedge accounting level, which is the opposite of hypothesis 3 tested, and the hedge accounting methodology would not be used for the non-violation of covenants. In the control variables, LEV and ROA were the only significant variables in the presence of the others with a positive relationship with the hedge accounting level variable.

\section{Table 11 - Results of Hedge Accounting and Covenants}

Panel E - Hedge Accounting and Covenants

$$
D U M M Y \_H A_{i j}=\varphi+\beta_{1} \text { SCov_Slack }_{i t-n}+\sum_{k=1}^{w} \text { Controls }_{i t-n}+e_{i j}
$$

\begin{tabular}{lcc}
\hline & $(\mathrm{N}=138)$ & $(\mathrm{N}=170)$ \\
Variables & Lagged & No Lagged \\
\hline Cov_Slack $\mathrm{t}_{-1}$ & -0.039 & -0.006 \\
Cov_Slack $\mathrm{t}$ & $(0.081)$ & $(0.025)$ \\
Controls & Yes & Yes \\
Dummy Industry & No & No \\
Dummy Year & No & No \\
Constant & Yes & Yes \\
Pseudo $\mathrm{R}^{2}$ & 0.356 & 0.264 \\
\hline$* * * \mathrm{p}<0.01, * * \mathrm{p}<0.05, * \mathrm{p}<0.1$ & &
\end{tabular}

Source: Authors

The DUMMY_H variable as independent, and the COV_SLACK lagged or nonlagged were not statistically significant. The adoption of this methodology is influenced by LEV, LIQ, SIZE, BETA, and the Proportion of derivatives. 
Based on these results, the only model in which Covenants Slack was significant was by HA_RATIO and with the non-lagged variable, but with a negative relationship, so it can be inferred that even in case of a relationship between these variables, the hedge accounting would have an opposite relationship with covenants slacks. Therefore, hypothesis 3 of proximity to covenants cannot be accepted as a determinant for the adoption of the higher level of adoption of derivatives for hedge accounting.

\subsubsection{Additional Analysis}

To identify a counterfactual effect of applying hedge accounting, we identified companies that applied cash flow hedge and had covenant clauses that involved items of financial expenses, financial income or financial results.

To include the variation found in the Other Comprehensive Income (OCI) the following criteria were used. For clauses containing Financial Result, the constant value of the constant cash flow hedge variation was added to the Financial Result regardless of the sign. For Financial Expense clauses, if the cash flow hedge change amount in the Comprehensive Income was negative, it would be summed, and if the value was positive, it would only be added to the Financial Income item clauses.

We found 66 observations that fit this situation. After recalculating the values, we found two companies that were able to comply with covenant clauses by applying hedge accounting.

Table 12 - Recalculation of Covenants Clauses

\begin{tabular}{lllll}
\hline Company & Covenant Clause & Limit & Calculated & Recalculated \\
& & Index & & \\
& & & & \\
\hline Celulose & EBITDA/Financial Expenses & 2.0 & 2.27 & 1.976 \\
Irani & & & &
\end{tabular}


$\begin{array}{lllll}\text { CCR S.A } & \text { EBIT/Financial Expenses } & 1.3 & 1.337 & 1.238\end{array}$

Source: Authors

\section{Final Considerations}

Due to the increased risk management practices by companies, it is important to identify the motivations and determinants of hedge accounting. To investigate this problem, we developed two new hedge accounting proxies. The first one was prepared by the notional ratio of hedge accounting and derivatives and non-derivatives and the other one by the clustering of this average ratio.

The first proxy was tested in the three hypotheses of this study and the second one, in hypotheses 1 and 2, contributing to evidence of the impact and determinants of the practice of hedge accounting on the firm value, earnings smoothing and violation of covenants.

The first hypothesis of this paper is based on the theoretical framework of the determinants of hedge and firm value maximization. Hedge accounting is an optional corporate practice that allows the hedging instrument to be matched with the hedged object and presents the economic essence of the transaction and more reliably identifies the transaction.

We present evidence in Hypothesis 1, which cluster companies that have a higher level of hedge accounting designation in the period, have a positive and significant relationship with the higher firm value. This research differs from the previous ones by using proxies that consider the level of hedge accounting designation and average hedge accounting cluster use in a period, and not just the option of using hedge accounting, which did not find this relationship.

This result does not necessarily mean that the practice of hedge accounting increases the firm value, but it shows evidence that the practice of hedge accounting 
(whose use has requirements) for companies that consistently adhere to this standard showed higher maximization of the firm value.

In hypothesis 2, we analyze the relationship between earnings smoothing and hedge accounting. Hedge accounting allows the volatility of derivative financial instruments to be reduced by matching the hedged item and the hedging instrument so that the change in fair value does not impact the period result and, therefore, accounting represents the risk management hedging activity effects of companies using financial instruments.

Based on the results presented, we can identify that companies that adopt lower volume or hedge accounting practice have higher income smoothing practice. These findings corroborate the literature that the practice of hedge accounting presents earnings smoothing. Due to the matching of derivatives and hedged items, companies would be less likely to practice earnings smoothing.

In hypothesis 3, we were the first study to analyze the accounting choice to adopt hedge accounting due to the violation of covenants. As widely studied in the accounting choice literature, managers make accounting choices in order to increase their results due to the proximity of accounting clause violation (Watts \& Zimmerman, 1986; Smith \& Warner, 1979; Holthausen \& Leftwich, 1983).

In this hypothesis, we do not found evidences that proximity to violate covenants as a determinant for adoption or for the higher level of adoption. derivatives for hedge accounting. These results corroborate the view of hedge accounting as the main purpose of a reliable representation of accounting operations and not as a practice of earnings management to intentionally reduce results for the period.

As an additional analysis, we found 66 companies which used cash flow hedges and had covenant clauses that allowed recalculation to identify whether any of them did 
not violate the clause as a result of hedge accounting. Only two companies were found to be able to comply with the covenant clause by adopting hedge accounting.

A suggestion for future research is the analysis of whether covenant slack is a possible determinant to the initial adoption of hedge accounting since the present work analyzed the level of hedge accounting adoption and not the initial adoption.

\section{References}

Allayannis, G., \& Weston, J. P. (2001). The use of foreign currency derivatives and firm market value. The review of financial studies, 14(1), 243-276.

Allayannis, G., \& Ofek, E. (2001). Exchange rate exposure, hedging, and the use of foreign currency derivatives. Journal of International Money and Finance, 20, 273-296. doi:10.1016/S0261-5606(00)00050-4

Aretz, K., \& Bartram, S. M. (2010). Corporate hedging and shareholder value. Journal of Financial Research, 33, 317-371. doi:10.1111/j.1475-6803.2010.01278.x

Barton, J. (2001). Does the use of financial derivatives affect earnings management decisions? The Accounting Review, 76, 1-26. doi:10.2308/accr.2001.76.1.1

Bartram, S. M., Brown, G. W., \& Conrad, J. (2011). The effects of derivatives on firm risk and value. Journal of Financial and Quantitative Analysis, 46, 967-999. doi:10.1017/S0022109011000275

Beatty, A., \& Weber, J. (2003). The effects of debt contracting on voluntary accounting method changes. The Accounting Review, 78, 119-142. doi: $10.2308 /$ accr.2003.78.1.119

Beaver, W., Kettler, P., \& Scholes, M. (1970). The association between market determined and accounting determined risk measures. Accounting Review, 45, 654-682.

Beidleman, C. (1973). Income smoothing: The role of management. Accounting Review, 48, 653-667.

Breeden, D. T., \& Viswanathan, S. (2015). Why Do Firms Hedge? An Asymmetric Information Model. Journal of Fixed Income, 25, 7-25. doi:10.3905/jfi.2016.25.3.007

Capelletto, L. R., de Oliveira, J. L., \& Carvalho, L. N. (2007). Aspectos do hedge accounting não implementados no Brasil. Revista de Administração, 42, 511-523.

DeMarzo, P. M., \& Duffie, D. (1995). Corporate incentives for hedging and hedge accounting. Review of Financial Studies, 8, 743-771. doi:10.1093/rfs/8.3.743

Dichev, I. D., \& Skinner, D. J. (2002). Large-sample evidence on the debt covenant hypothesis. Journal of Accounting Research, 40, 1091-1123. doi:10.1111/1475679X.00083

de Matos, E. B. S. de, de Rezende, R. B. , de Paulo, E., de Marques, M. de M., \& Ferreira, L. O. G. (2013). Utilização de Derivativos e Hedge Accounting nas Empresas Brasileiras e Japonesas Negociadas na NYSE. Revista de Contabilidade e Controladoria, 5(2), 74-90. doi: 10.5380/rcc.v5i2.30410

dos Santos, R. B., Lima, F. G., Gatsios, R. C., \& de Almeida, R. B. (2017). Risk management and value creation: New evidence for Brazilian non-financial companies. Applied Economics, 49, 5815-5827. doi: $\underline{10.1080 / 00036846.2017 .1343451}$ 
Fields, T. D., Lys, T. Z., \& Vincent, L. (2001). Empirical research on accounting choice. Journal of Accounting and Economics, 31, 255-307. doi:10.1016/S01654101(01)00028-3

Froot, K. A., Scharfstein, D. S., \& Stein, J. C. (1993). Risk management: Coordinating corporate investment and financing policies. Journal of Finance, 48, 1629-1658. doi:10.1111/j.1540-6261.1993.tb05123.x

Galdi, F. C., \& Guerra, L. F. G. (2009). Determinantes para utilização de Hedge Accounting: Uma escolha contábil. Revista de Educação e Pesquisa em Contabiilidade, 3, 23-44.

Glaum, M., \& Klöcker, A. (2011). Hedge accounting and its influence on financial hedging: When the tail wags the dog. Accounting and Business Research, 41, 459489. doi:10.1080/00014788.2011.573746

Graham, J. R., Harvey, C. R., \& Rajgopal, S. (2005). The economic implications of corporate financial reporting. Journal of Accounting and Economics, 40, 3-73. doi:10.1016/j.jacceco.2005.01.002

Holthausen, R. W., \& Leftwich, R. W. (1983). The economic consequences of accounting choice implications of costly contracting and monitoring. Journal of Accounting and Economics, 5, 77-117. doi:10.1016/0165-4101(83)90007-1

Hughen, L. (2010). When do accounting earnings matter more than economic earnings? Evidence from hedge accounting restatements. Journal of Business Finance and Accounting, 37, 1027-1056. doi:10.1111/j.1468-5957.2010.02216.x

Hull, J. (2005). Fundamentos dos mercados futuros e de opções (4 ed.). São Paulo, Brazil: Bolsa de Mercadorias and Futuros.

Jensen, M. C., \& Meckling, W. H. (1976). Theory of the firm: Managerial behavior, agency costs and ownership structure. Journal of Financial Economics, 3, 305360. doi:10.1016/0304-405X(76)90026-X

Judge, A. (2007). Why do firms hedge? A review of the evidence. In Issues in finance and monetary policy (pp. 128-152). London: Palgrave Macmillan.

Kim, B., Lisic, L., \& Pevzner, M. (2011). Debt covenant slack and real earnings management. Working Paper. American University.

Kothari, S. P., Leone, A. J., \& Wasley, C. E. (2005). Performance matched discretionary accrual measures. Journal of Accounting and Economics, 39, 163197. doi:10.1016/i.jacceco.2004.11.002

Lins, K. V., Servaes, H., \& Tamayo, A. (2011). Does fair value reporting affect risk management? International survey evidence. Financial Management, 40, 525-551. doi:10.1111/j.1755-053X.2011.01152.X

Lopes, A. B., Galdi, F. C., \& Lima, I. S. (2011). Manual de contabilidade e Tributação de instrumentos financeiros e derivativos. 2 São Paulo, Brazil: Atlas Press.

Mayers, D., \& Smith, C. W. (1982). On the corporate demand for insurance. Journal of Business, 55, 281-296. doi:10.1086/296165

Michelson, S. E., Jordan-Wagner, J., \& Wootton, C. W. (1995). A market based analysis of income smoothing. Journal of Business Finance and Accounting, 22, 1179-1193. doi:10.1111/j.1468-5957.1995.tb00900.x

Modigliani, F., \& Miller, M. H. (1958). American Economic Association. Source. American Economic Review, 48, 261-297.

Panaretou, A., Shackleton, M. B., \& Taylor, P. A. (2013). Corporate risk management and hedge accounting. Contemporary Accounting Research,30, 116-139. doi:10.1111/j.1911-3846.2011.01143.x

Pierce, S. (2015). Does the accounting for derivatives affect risk and value? Working paper. Florida State University. 
Pincus, M., \& Rajgopal, S. (2002). The interaction between accrual management and hedging: Evidence from oil and gas firms. The Accounting Review, 77, 127-160. doi:10.2308/accr.2002.77.1.127

Potin, S. A., Bortolon, P. M., \& Neto, A. S. (2016). Hedge accounting no mercado acionário brasileiro: Efeitos na qualidade da informação contábil, disclosure e assimetria de informação. Revista Contabilidade e Finanças, 27, 202-216. doi: 10.1590/1808-057x201602430

Silva, F. C. (2014). Hedge accounting no Brasil [Tese de Doutorado]. São Paulo, Brazil: Universidade de São Paulo.

Smith, C. W., \& Stulz, R. M. (1985). The determinants of firms' hedging policies. Journal of Financial and Quantitative Analysis, 20, 391-405. doi: $10.2307 / 2330757$

Smith, Jr., C. W., \& Warner, J. B. (1979). On financial contracting: An analysis of bond covenants. Journal of Financial Economics, 7, 117-161. doi:10.1016/0304405X(79)90011-4

Stulz, R. M. (1984). Optimal Hedging policies. Journal of Financial and Quantitative Analysis, 19, 127-140. doi:10.2307/2330894

Subramanyam, K. R. (1996). The pricing of discretionary accruals. Journal of Accounting and Economics, 22, 249-281. doi:10.1016/S0165-4101(96)00434-X

Tessema, A., \& Deumes, R. (2018). SFAS 133 and income smoothing via discretionary accruals: The role of hedge effectiveness and market volatility. Journal of International Financial Management and Accounting, 29, 105-130. doi:10.1111/jifm.12070

Trueman, B., \& Titman, S. (1988). An explanation for accounting income smoothing. Journal of Accounting Research, 26, 127-139. doi:10.2307/2491184

Tucker, J. W., \& Zarowin, P. A. (2006). Does income smoothing improve earnings informativeness? The Accounting Review, 81, 251-270. doi:10.2308/accr.2006.81.1.251

Watts, R.L. and Zimmerman, L.L. (1986), Positive Accounting Theory, Prentice Hall, Upper Saddle River, NJ.

Watts, R. L., \& Zimmerman, J. L. (1990). Positive accounting theory: A ten year perspective. Accounting Review, 65, 131-156.

Zhang, H. (2009). Effect of derivative accounting rules on corporate risk-management behavior. Journal of Accounting and Economics, 47, 244-264. doi:10.1016/j.jacceco.2008.11.007 